OPS-RMT- 900200

DE92 013271

\title{
HEAVY METAL CONTAMINATION IN TIMS BRANCH SEDIMENTS (U)
}

\author{
WSRC Contact:
}

W. H. Carlton

Westinghouse Savannah River Co.

Savannah River Site

Aiken, South Carolina 29808

A technical report being sent to OSTI and for distribution to the general public.

\section{DISCLAIMER}

\begin{abstract}
This report was prepared as an account of work sponsored by an agency of the United States Government. Neither the United States Government nor any agency thereof, nor any of their employees, makes any warraniy, express or implied, or assumes any legal liability or responsibility for the accuracy, completeness, or usefulness of any information, apparatus, product, or process disclosed, or represents that its use would not infringe privately owned rights. Reference herein to any specific commercial product, process, or service by trade name, trademark, manufacturer, or otherwise does not necessarily constitute or imply its endorsement, recommendation, or favoring by the United States Government or any agency thereof. The views and opinions of authors expressed herein do not necessarily state or reflect those of the United States Government or any agency thereof.
\end{abstract}

This report was prepared in connection with work done under Contract No. DE-AC09-89SR18035 with the U.S. Department of Energy. By acceptance of this paper, the publisher and/or recipient acknowledges the U.S. Government's right to retain a nonexclusive, royalty-free license in and to any copyright covering this paper, along with the right to reproduce and to authorize others to reproduce all or part of the copyrighted paper. 


\section{DISCLAIMER}

This report was prepared as an account of work sponsored by an agency of the United States Government. Neither the United States Government nor any agency thereof, nor any of their employees, makes any warranty, express or implied, or assumes any legal liability or responsibility for the accuracy, completeness, or usefulness of any information, apparatus, product, or process disclosed, or represents that its use would not infringe privately owned rights. Reference herein to any specific commercial product, process, or service by the trade name, trademark, manufacturer, or otherwise, does not necessarily constitute or imply its endorsement, recommendation, or favoring by the United States Government or any agency thereof. The views and opinions of authors expressed herein do not necessarily state or reflect those of the United States Government or any agency thereof. 

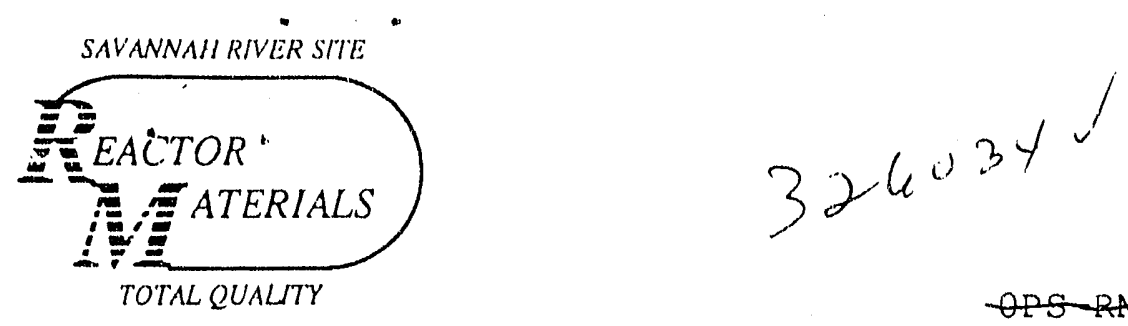

$\theta P S-R+20=x \times x \times x$

WESTINGHOUSE SAVANNAH RIVER COMPANY

\section{INTER-OFFICE MEMORANDUM}

OPS-RMT-900200

June 25, 1990

TO: W. L. MCDOWELL, 735-A

SRL, ENVIRONMENTAL TECHNOLOGY SECTION

FROM: J. B. PICKETT, 730-M (5-3838) MPA Th

REACTOR MATERIALS ENGINEERING AND TECHNOLOGY

HEAYY METAL CONTAMINATION IN TIMS BRANCH SEDIMENTS

\section{BACKGROUND}

The Environmental Technology Section (ETS) of the Savannah River Laboratory is currently preparing a number of reports for the site Radiological Assessment Program (RAP). The Radiological Asscssmenl Program was requested by the Savannah River Department of Encrgy (SR-DOE). One of the sections of the RAP is a report, "Uranium in the SRS Environment" and Chapter 2 of the report will include surface water transport of uranium, including Stecd's Pond and Tims Branch.

The objective of this memorandum is 10 summarize results of previous sediment studies on Tims Branch and Steed's Pond conducted by Health Protection (HP) and by the Savannah River Laboratory (SRL) in conjunction with Reactor Materials Engineering \& Technology (RMET). The results for other heavy metals, such as lead, nickel, copper, mercury, chromium, cadmium, zinc, and thorium are also summarized.

The data indicate that each of the hcavy metals is substantially elevated in the sediments of Tims Branch, downstream of the confluence with the influent discharge ditches from the 300/700 Arcas (outfalls A-014, A-011, and A-008). It is assumed that the high concentrations of metals are mainly due to $\mathrm{M}$-Area discharges to the Tims Branch System from $\sim 1952$ to 1973, at which time the discharge from Building 313-M was diverted to the M-Area Settling Basin. It may be noted that the types of constituents, and their relative concentrations, are similar to the characterization of the sludge and sediments associated with the M-Area Settling Basin (Reference 1).

\section{SCOPE}

The scope of this report is limited 10 those studies which have been reported by Health Protection or to studies conducted by SRL - under an M-Area RTA (Request for Technical Assistance). This report is not intended to be an exhaustive study of the Tims Branch system, but to provide a summary for the RAP report preparation. This report also contains the results of sediment analyses conducted by SRL/RMET in 1985/1986, which have not been previously published in an internal memorandum.

* Document No. OPS-RMT-900200 assigned July 18,1990. 
Page 2 of 10

June 26,1990

\section{RESULTS}

\section{Steed's Pond Data (HP)}

The Health Protection Department(HP) conducted a study of the sediments in Steed's Pond in 1967 (Reference 2). In 1966. detcrioration of the spillway of the old farm pond had allowed the pond 10 drain, and as the pond drained, vegetation rapidly covered portions of the sediments as they bccame exposed. Eighteen inch deep core samples were collected from 4 acres of unvegetated area and a total of 1.1 curies of uranium was calculated to be present. If the concentration in the remainder of the grassy region ( 9 acres) is similar, then the entire 13 acres would contain $3-4$ curies of uranium $(20,000$ to 26,000 lbs of natural uranium). Since both the vegetated and unvegetated areas had been covered by the water in the pond, it is a not unreasonable assumption that both arcas would have similar sediment concentrations.

This may be compared to the total of 9.3 curics of uranium that was monitored in the M-Area releases to Tims Branch from 1955 thru 1966 (Reference 3).

A map of the Tims Branch and Stecd's Pond system is given in Figure 1.

\section{Uranium Releases thru 1925 (HP)}

In 1977, it was reported in the Final Environmenl Impact Statement, "Waste Management Operations for the Savannah River", (Reference 4), that a total of 24 (23.6) $\mathrm{Ci}(\sim 86,000 \mathrm{lbs})$ of natural uranium had been released to Tims Branch from the $300-\mathrm{M}$ area through 1975.

\section{Radiological Survey with Tims Branch. Steed's Pend (HP)}

In 1977 a radiological survey of Tims Branch and Steed's Pond was conducted by the Health Protection Department (Reference 5). The data indicated no detectable levels of thorium and uranium in the Tims Branch System above its confluence with the 300-M effluent discharges ditch. Cores from the 300-M effluent ditch, and from the braided streams in Tims Branch downstream of the 300-M effluent confluence, contained from 10 to $27 \mathrm{pci} / \mathrm{gm}$ sediment $(30$ to $85 \mathrm{ppm})$ of natural uranium, and from 4 to $13 \mathrm{pci} / \mathrm{gm}$ (36 to $117 \mathrm{ppm}$ ) of natural thorium.

The two sediment cores collected from Steed's Pond in 1977 did not have $U$ or Th concentrations above background. However, these cores were taken at the edge of the pond and would not have reflected deposition in the deeper portions of the pond. The sample locations are shown in Figure 2 (from Reference 5). The sediments from the deeper area of the pond were subsequently sampled in 1984 (see below).

\section{Menitoring of Steed's Pond and Tims Branch in 1984 (HP)}

A partial failure of the wooden dam at Steed's Pond occurred in August, 1984. Following the dam failure, special water and sediment samples were collected by HP to determine if radioactivity were migrating from the pond.

Concentrations of uranium $(1.9 \mathrm{pCi} / \mathrm{L})$ and nonvolatile beta $(4.9 \mathrm{pCi} / \mathrm{L})$ in the water from the mouth of Tims Branch were within the range of concentrations routinely 
measured before the dam failure. Maximum concentrations in sediment in the pond bed were $490 \mathrm{pCi} / \mathrm{g}$ of uranium and $410 \mathrm{pCi} / \mathrm{g}$ of nonvolatile beta, (1984 Environment Report, Reference 6).

Additional analytical results on these sediment samples were included in the 1985 Environment Report (Reference 7). This report gave the concentrations of a number of heavy metals in addition to uranium, and are summarized below:

Maximum Scdiment Concentralion
Southeastern USA(Ref. 8)

\section{concentration}

Range
$11-60$
$9-36$
$3-26$
$3-18$
$<200-2,500$
$900-46,000$
$1.6-5.5^{* *}$
$5-15^{* * *}$

* Excluding an anomalous valuc of $2100 \mathrm{ug} / \mathrm{g}$.

* * SRP results

*** Wyoming and Montana levels

The concentrations of all of the heavy metals tested were significantly higher than other soils on the SRP site, or in the upper soil horizons of the southeastern USA. Nickel and uranium were 500 10 3000 times higher, respectively, than "normal" soil concentrations. $\mathrm{Cr}, \mathrm{Cu}, \mathrm{Pb}$, and $\mathrm{Th}$ were 5 to 10 limes higher.

The higher concentrations of the heavy mctals were usually found in the upper 6 to 18 inches of sediment, and the highest concentrations were found in the sediments in Steed's Pond nearest to the dam site. All of the data is presented in Table 3-54, Volume II of the 1985 Environmental Report (Reference 7).

A core sample taken immediately downstream of the Steed's Pond dam site indicated a uranium concentration of $3 \mathrm{pCi} / \mathrm{g}$. This result indicates that most of the uranium released from the fuel preparation area was deposited in Tims Branch above Steed's Pond and in Steed's Pond.

\section{Contaminant Transport Studies in Tims Braich (SRL)}

A study was conducted by SRL in 1985 to determine the impact the Steed's Pond dam failure (in 1984) on the subscquent transport of contaminants downstream (Reference 9). The study showed that the amount of sediment transported to Upper Three Runs Creek (about 2 miles downstream of Stced's Pond) was about the same as in past years, prior to the collapse of the spillway. I? was stated in the report that what little erosion that could occur in the cxposed sediments of Steed's Pond would be reduced as revegetation of the sediments 0ccurred. The results of the sediment transport study indicated that Stecd's Pond could be left in a drained condition without affecting suspended solids concentrations or the associated uranium concentrations in Upper Three Runs Crcck. 
W. L. McDowell, 735-A

OPS-RMT-900200

Page 4 of 10

June 26,1990

Uranium Releases thru 1985 (HP)

In 1986, it was reported in DPSPU-86-25-1 (Ref, 10) that a total of $24.6 \mathrm{Ci}$ of uranium had been released to Tims Branch. This would be approximately a $1 \mathrm{Ci}$ increase since 1975, and would represent $\sim 6600 \mathrm{lbs}$ of depleted uranium. The total amount through 1985 would thercfore be approximatcly 92,000 lbs. of natural and depleted uranium. Uranium releases to Tims Branch have been negligible since 1985, due to the construction and operation of the M-Area Liquid Effluent Treatment Facility (LETF).

\section{5-1986 Tims Branch Chemical and Biological Study (SRL/BMET)}

A chemical and biological study was conducted by SRL in 1985-1986 on the Tims Branch system, with the objective 10 detcrmine the impacts of the effluents from M-Area's Dilute Effluent Treatment Facility (DETF) on the receiving stream.

Sediment concentrations of various metals were decermined monthly at 6 locations in Tims Branch and upper Three Runs Creck from Iune 1985 to June, 1986 (Ref. 11).

The sampling locations are shown in Figure 3. The locations TB-2 was the control sampling location as it was upstream of the confluence of the M-Area effluent discharge ditch and Tims Branch. Location TB-1 was downstream of the confluence of the outfall ditch and Tims Branch. TB-3 was approximately 100 yards downstream of the ssillway from Steed's Pond and TB-4 was located on Tims Branch approximately 400 yards before its confluence with Upper Three Runs creek. TB-5 and TB-6 were in Upper Three Runs, upstream and downstream of the confluence with Tims Branch, respectively.

The sediment concentrations of all metals tested were highest at Site TB-1 (Table 1). The average concentration of uranium at the TB-1 sediment location was $1550 \mathrm{mg} / \mathrm{kg}$ $(\mathrm{ppm})$, as compared with $0.21 \mathrm{ppm}$ at the reference site, TB-2. Sediment uranium concentrations decreased progressively downstream; TB-3 and TB-4 had averages of 55 and $20 \mathrm{ppm}$, respectively. A similar situation existed regarding sediment nickel, as its average values increased from $2.4 \mathrm{ppm}$ at TB-2 $10780 \mathrm{ppm}$ at TB-1, then decreased to 29 and $25 \mathrm{ppm}$ at $\mathrm{TB}-3$ and $\mathrm{TB}-4$, respectively.

The average sediment concentrations of mclals other than uranium and nickel (Al, $\mathrm{Cu}, \mathrm{Pb}, \mathrm{Hg}$, and $\mathrm{Zn}$ ) were also highest at TB-1 (Table 1). However, the concentrations of these other metals appeared to be related to Total Organic Matter (TOM) in the sediment. A positive relationship betwecn concentrations of metals and organic matter is not unexpected, because these motals may form stable complexes with organic matter or tend to be concentrated by the biota comprising the TOM.

\section{Potential Groundwater Impact}

A limited number of groundwater munitoring wells have been installed in the Tims Branch/Steed's Pond area, as a portion of the A/M-Area plume definition well system. These wells have been used to track the concentrations of chlorinated hydrocarbons, and heavy metal analyses have not been conducted. Contamination of the groundwater due to the deposition in the sediments of Tims Branch is, however, very unlikely, since Tims Branch is a "gaining strcam". Eg., the water table outcrops into Tims Branch, which will therefore inhibit the transport of contaminants into the groundwater. 
W. L. McDowell, 735-A

Page 5 of 10

June 26, 1990

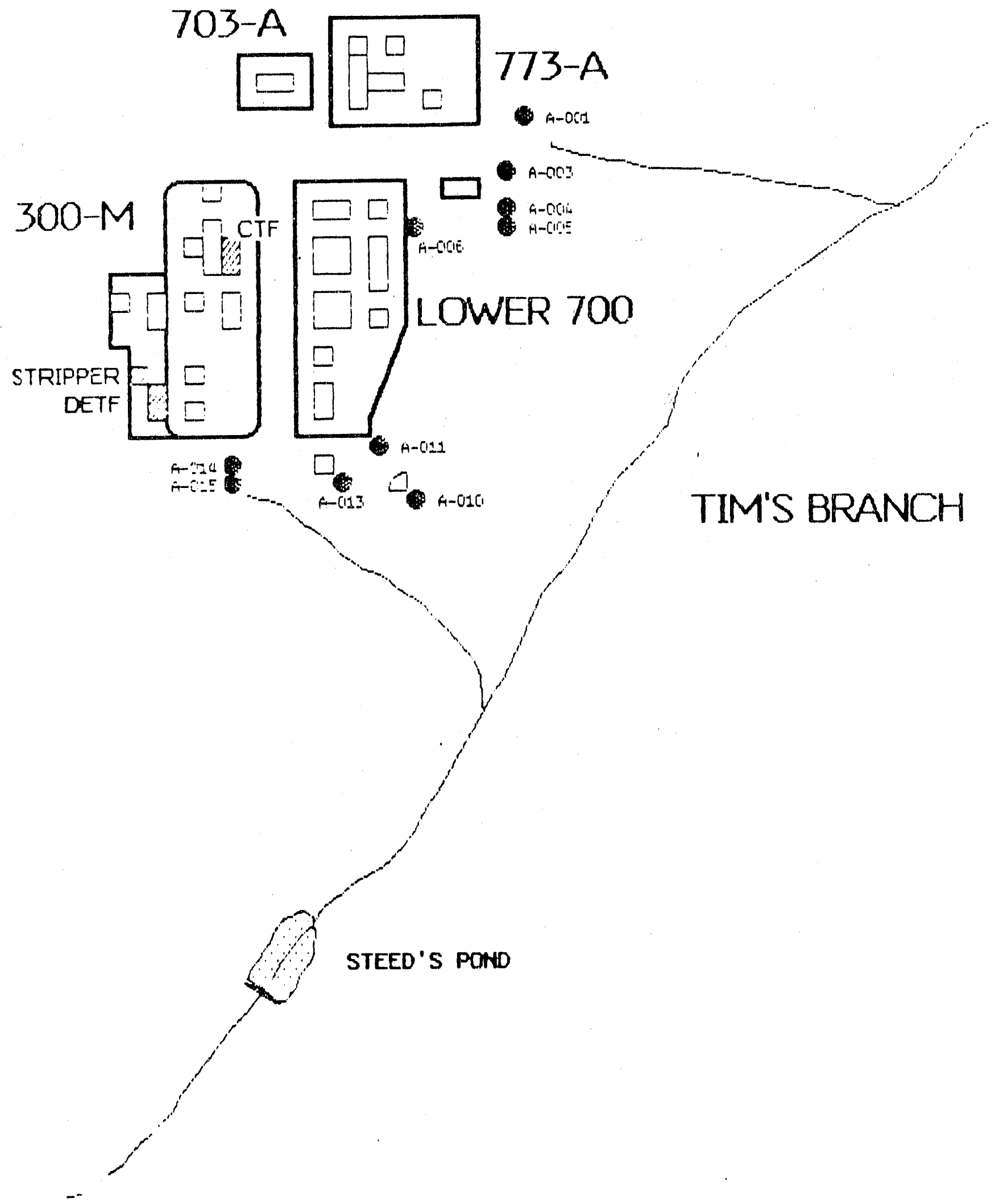

Figure 1. 300/700 Area Map 


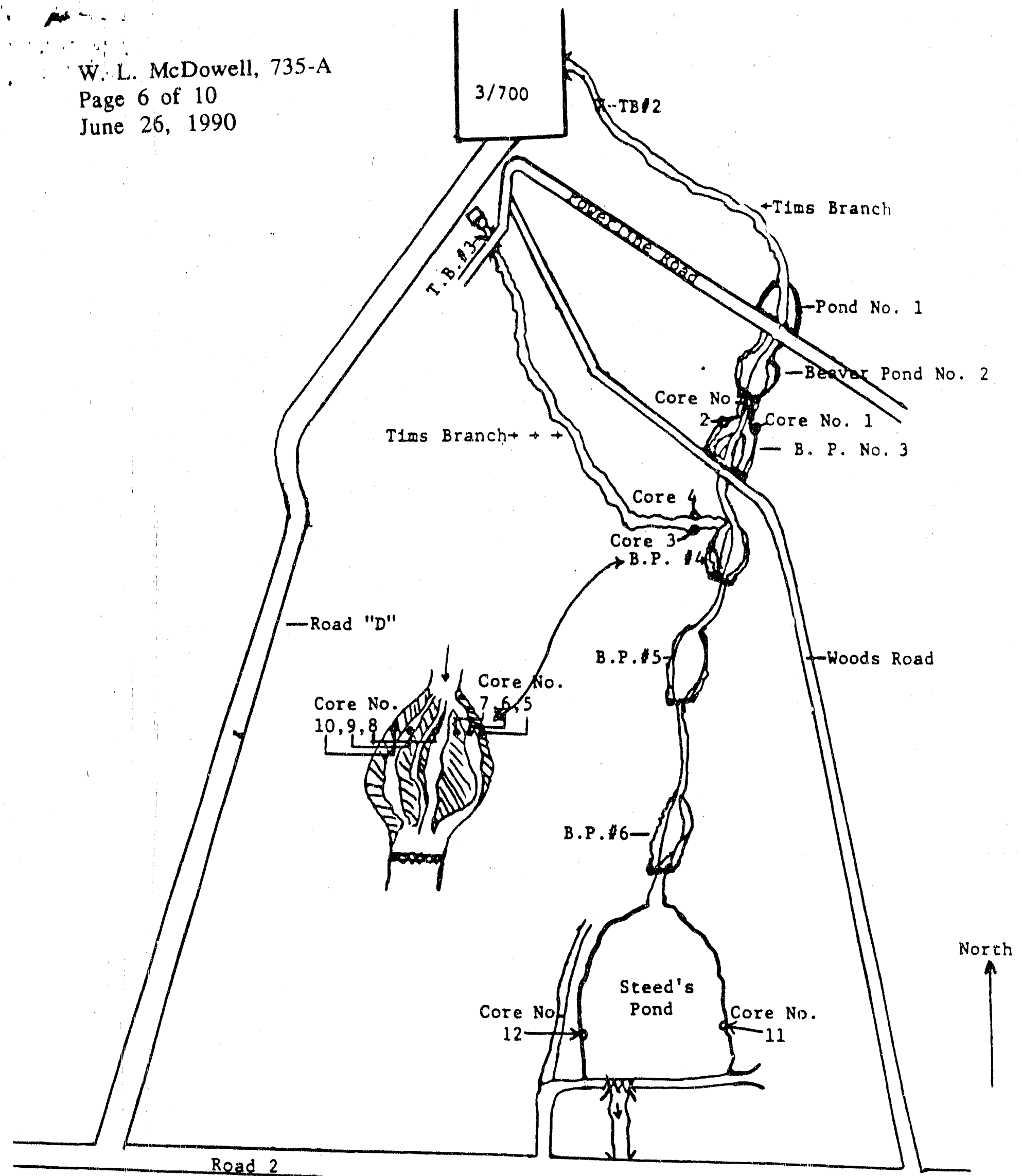

Road 2

Figure 2. Sampling Locations, 1977 HP Survey 
W. L. McDowell, 735-A

Page 7 of 10 June 26,1990

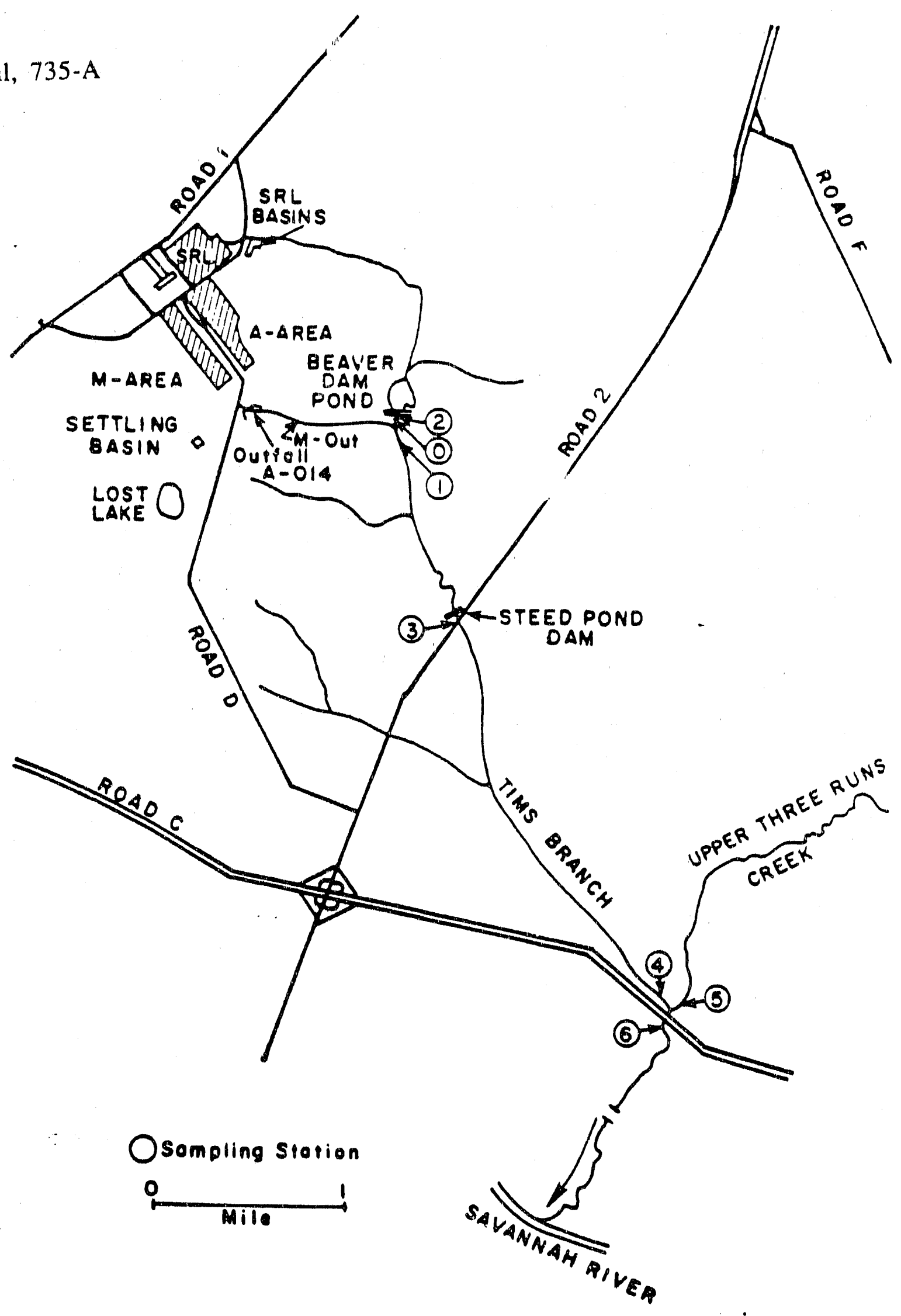

Figure 3. Sampling Locations, 1985-1986 Tims Branch Study 
W. L. McDowell, 735-A

Páge 8 of 10

June 26,1990

TABLE 1

SEDIMENT CHEMICAL RESULTS AT SITES ON TIMS BRANCH JUNE 1985 - JUNE 1986

SAMPLING LOCATION

\begin{tabular}{|c|c|c|c|c|c|c|c|}
\hline \multicolumn{2}{|c|}{$\begin{array}{l}\text { CONSTITUENT } \\
\mathrm{mg} / \mathrm{kg}=\mathrm{ppm})\end{array}$} & $\begin{array}{l}\text { TB.2 } \\
\text { Background }\end{array}$ & $\begin{array}{l}\text { TB-1 } \\
\text { Aftur } \\
\text { confluence } \\
\end{array}$ & $\begin{array}{l}\text { TB-3 } \\
\text { Below } \\
\text { Steed's Pond } \\
\end{array}$ & $\begin{array}{l}\text { TB.4 } \\
\text { Before } \\
\text { Upper } 3 \text { Runs }\end{array}$ & $\begin{array}{l}\text { TB.5 } \\
\text { Upstream } \\
\text { on U3A } \\
\end{array}$ & $\begin{array}{l}\text { TB-6 } \\
\text { Downstream } \\
\text { on U3R } \\
\end{array}$ \\
\hline$U$ & mean & 0.21 & 1547.4 & 55.25 & 19.86 & 11.26 & 12.39 \\
\hline & SE & 0.12 & 266.2 & 10.10 & 4.47 & 3.38 & 2.51 \\
\hline & $n$ & 8 & 8 & 8 & 8 & 8 & 8 \\
\hline $\mathrm{Ni}$ & mean & 2.40 & 783.0 & 28.87 & 24.67 & 9.58 & 13.09 \\
\hline & SE & 0.51 & 228.9 & 6.08 & 6.33 & 2.28 & 1.20 \\
\hline & $n$ & 8 & 8 & 8 & 8 & 8 & 8 \\
\hline $\mathrm{Cu}$ & mean & 3.19 & 74.71 & 2.11 & 1.39 & 10.02 & 6.13 \\
\hline & SE & 0.64 & 15.45 & 0.29 & 0.45 & 2.74 & 1.14 \\
\hline & $n$ & 8 & 8 & 8 & 8 & 8 & 8 \\
\hline $\mathrm{Al}$ & mean & 6010 & 46761 & 2739 & 1563 & 9099 & 7046 \\
\hline & $S E$ & 1181 & 4009 & 434 & 243 & 1436 & 1183 \\
\hline & $n$ & 8 & 8 & 8 & 8 & 8 & 8 \\
\hline $\mathrm{Fe}_{\theta}$ & mean & 57917 & 52425 & 7402 & 2743 & 5165 & 5083 \\
\hline & $S E$ & 1439 & 8063 & 1076 & 577 & 677 & 1034 \\
\hline & $n$ & 8 & 8 & 8 & 8 & 8 & 8 \\
\hline $\mathrm{Hg}$ & mean & 0.025 & 0.402 & 0.017 & 0.010 & 0.048 & 0.039 \\
\hline & SE & 0.009 & 0.029 & 0.005 & 0.002 & 0.008 & 0.003 \\
\hline & $n$ & 8 & 8 & 8 & 8 & 8 & 8 \\
\hline $\mathrm{Cr}$ & mean & 7.21 & 80.21 & 5.50 & 3.24 & 14.48 & 11.61 \\
\hline & SE & 0.59 & 8.65 & 0.49 & 0.54 & 2.22 & 2.27 \\
\hline & $n$ & 8 & 8 & 8 & 8 & 8 & 8 \\
\hline $\mathrm{Cd}$ & mean & 0.122 & 1.51 & 0.079 & 0.077 & 0.75 & 0.40 \\
\hline & SE & 0.035 & 0.22 & 0.015 & 0.016 & 0.28 & 0.07 \\
\hline & $n$ & 8 & 8 & 8 & 8 & 8 & 8 \\
\hline $\mathrm{Zn}$ & mean & 13.90 & 128.2 & 6.51 & 5.21 & 29.75 & 19.56 \\
\hline & SE & 2.32 & 11.4 & 1.17 & 1.14 & 5.73 & 6.00 \\
\hline & $n$ & 8 & 8 & 8 & 8 & 8 & 8 \\
\hline $\mathrm{Pb}$ & mean & 2.02 & 33.72 & 1.69 & 1.68 & 6.73 & 3.90 \\
\hline & SE & 0.19 & 5.74 & 0.23 & 0.14 & 1.12 & 3.78 \\
\hline & $n$ & 8 & 8 & 8 & 8 & 8 & 8 \\
\hline & $M(\% \text { L.O.I. })^{*}$ mean & 2.66 & 25.07 & 1.01 & 2.12 & 6.32 & 7.72 \\
\hline & $S E$ & 0.28 & 0.87 & 0.18 & 0.34 & 0.77 & 0.56 \\
\hline & $n$ & 31 & 31 & 31 & 31 & 31 & 31 \\
\hline
\end{tabular}

-TOM = Total Organic Matter, \% loss on ignition 
Page 9 of 10

June 26,1990 .

\section{Beferences}

1. Pickett, J. B., 1985. Technical Data Summary, Extended Characterization of the M-Area Settling Basin and Vicinity, DPSTD-8̈s-121, (Rev. 10/85), E. I. du Pont de Nemours and Company, Savannals River Laboratory, Aiken, SC.

2. SRL Monthly Report, 1967. DP-67-1-2, February, pp 121-122.

3. Ashley, C., and Zeigler, C. C., 1980. Releases of Radioactivity at the Savannah River Plant, 1954 Through 1978, DPSPU 75-25-1, E. I. du Pont de Nemours and Company, Savannah River Plant.

4. Final Environmental Impact Statement Waste Management Operations, Savannah River Plant, Aiken, SC, 1977. ERDA-1537, pp III-11 and 12.

5. Rabon, E. W. to Ross, D. I., 1978. Radiological Survey of Tims Branch - Steed's Pond, Inter-office Memorandum, Savannah River Plant.

6. Savannah River Plant Environmental Report for 1984, DPSPU-85-30-1, E. I. du Pont de Nemours and Company, Savannah River Plant, Aiken, SC.

7. Zeigler, C C., Lawrimore, I, B., Hcalh, E. M., and Till, J. E., Savannah River Plant Environmental Report, Annual Report for 1985, DPSPU-86-30-1, E. I. du Pont de Nemours and Company, Savannah River Plant, Aiken, SC.

8. Pickett, J, B., Colven, W. P., and Bledsoc, H. W., 1985. Environmental Information Document, M-Arca Scttling Basin and Vicinity, DPST-85-703, E. I. du Pont de Nemours and Company, Savannah River Laboratory, Aiken, SC.

9. Hayes, D. W., 1986. Sediment Transport Studies in Tims Branch, DPST-86-468, E. I. du Pont de Nemours, Savannah River Laboratory, Aiken, SC.

10. Releases of Radioactivity at the Savannah River Plant, 1954 through 1985 , 1986. DPSPU 86-25-1, E. I. du Pont de Nemours and Company, Savannah River Plant, Aiken SC.

11. Starkel, W. M., Giffin, M., and Trapp, K. E., 1987. Biological and Chemical Assessment of M-Area Process Discharge to Tims Branch, June 1985 December, 1986, ESC-SR-43, Environmental and Chemical Science, Inc., Aiken, SC. 
Page 10 of 10

June 26,1990

CC. A. E. Hadden, 73()-M

R. A. Lce, 730-M

C. P. Thompson, 730-M

C. R. Sherman, 703-A

J. R. Gladden, 773-42-A

W. L. Specht, 773-42-A

E. A. Campbell, 703-A

J. G. Horvath, 320-4M

M. P. Wilson, 703-A

D. D. Hoel, 735-A

D. W. Hayes, 773-A

J. E. Pinder, SREL

T. M. Thomton, 730-M, RMET Environmental File

Central Files, 703-A

JBP:tmt 
